\title{
Telerrealidad y aprendizaje social
}

\author{
$M^{\mathrm{a}}$ Dolores Cáceres \\ Profesora de Teoría de la Comunicación. Universidad Complutense de Madrid.
}

\begin{abstract}
Resumen
Esta colaboración es el resultado de la realización de numerosos análisis de programas de televisión que estudian las nuevas modalidades expresivas que ha adoptado la televisión en España durante los últimos años y que exploran sus posibilidades y limitaciones. El artículo presenta una reflexión a propósito de la virtualidad de la televisión, en concreto de los programas de telerrealidad, como instrumento de aprendizaje social. Estos programas parten de la realidad de la mano, principalmente, de sujetos anónimos, pero con un tratamiento basado en la espectacularización que los aleja de ella: son una construcción mediática y social no exenta de valores e ideología.
\end{abstract}

\section{Palabras clave}

telerrealidad, aprendizaje social, modelos sociales, espectacularización, televisión

\section{Abstract}

This paper is the result of making various analysis of different telelvision programmes which study the new kinds of expression that the spanish television has adopted during the last years, and which investigate its posibilities and limits. The article reflects about the virtuality of the television, reality programmes in particular, as an instrument of social learning. This programmes start from the reality of the hand basically on anonym people, but with a treatment based on the spectacularization which distances them from it: they are a social and mediatic construction not exempt from values and ideology. 


\section{Key words}

reality shows, social learning, social models, spectacularization, television

\section{Introducción}

Desde comienzos de los años noventa, hemos asistido en nuestro país, al igual que en los países de nuestro contexto más próximo, a cambios en la televisión que se llevan a cabo de forma paulatina y que han desembocado en una televisión de mercado en la que todas las cadenas generalistas compiten con productos similares por las mismas audiencias. Estos cambios, que arrancan del proceso de desregulación y aparición de las cadenas privadas, van más allá de la mera evolución en las formas comunicativas. Para posicionarse ventajosamente en un mercado altamente competitivo como el audiovisual, las televisiones han sufrido profundas transformaciones en los modos expresivos, los discursos, los contenidos y los propios actores de la comunicación. Estos cambios en la forma de ser y hacer de la televisión se relacionan con otras tantas cuestiones que derivan de aquellas transformaciones, cuál son las relativas al aprendizaje social que se origina a partir de un conjunto de programas que tienen un peso importante en las parrillas de las cadenas y notable éxito de audiencia, y que se denominan en la actualidad telerrealidad. Esta colaboración presenta una reflexión crítica a partir del resultado de la realización de numerosos análisis de dichos programas, que estudian las nuevas modalidades expresivas que ha adoptado la televisión en España durante los últimos años y que exploran su virtualidad y sus limitaciones.

U. Eco distinguió a mediados de los años ochenta (Eco, 1986: 200) dos etapas en la historia de la televisión: la Paleotelevisión existente hasta ese momento, y la Neotelevisión que se produce en el momento presente. En la primera época, la televisión era un escaparate de la realidad, una ventana que se abría al mundo para mostrarlo y dar a conocer los acontecimientos que se producen en el seno de las relaciones sociales y a sus actores. En el momento actual, la televisión se ha 
convertido en espejo de la realidad: imagen refleja de la cotidianidad en la que se ve representado el espectador y su entorno.

Esta distinta concepción de la televisión puede entenderse a partir del doble sentido que cobra la tensión dentro-fuera. En la televisión-escaparate o Paleotelevisión, el medio sale fuera para mostrar la realidad, las cámaras se trasladan al mundo real para dar cuenta de lo que allí acaece. Los sujetos que protagonizan los acontecimientos de referencia son actores sociales (políticos, líderes de opinión, estrellas del medio, profesionales de la escena o del espectáculo) cuya acción no se asemeja a la actividad cotidiana de la audiencia. Por ejemplo, los programas de actualidad o reportajes, magazines, programas de entrevistas, entretenimiento, etc. mostraban sujetos que no se parecen a los espectadores del medio, personas comunes alejadas por lo general de la esfera pública. Sin embargo en la Neotelevisión es la realidad la que penetra dentro de la televisión, la realidad es trasladada al plató, y allí se re-produce y se re-crea. Así lo ponen de manifiesto numerosos programas en donde la gente común relata las avatares de su vida personal -talk shows-, otros en los que el plató se convierte en escenario de confesiones, encuentros, reconciliaciones, disputas -reality shows-, o aquellos en los que se crea ex profeso una realidad para ser mostrada y seguida minuciosamente día a día por la audiencia -por ejemplo, Gran Hermano-.

\section{El poder socializador de las interacciones simbólicas}

En la actualidad nadie pone en cuestión la influencia de los medios en general y de la televisión en particular, a la hora de transmitir un universo simbólico de referencia común, crear realidad y generar pautas de comportamiento social.

Desde que los medios de comunicación permiten desvincular la interacción del espacio físico compartido por los actores, los medios asumen un papel socializador junto con otras instancias intencionales a tales efectos, como la familia o la escuela, y la acción del medio. A partir de la implantación masiva de las interacciones comunicativas con mediación tecnológica en la sociedad, se conforma un nuevo modo de adquisición de conocimientos y experiencia del mundo, desligado del contacto directo con los otros. La construcción del yo y la conformación de la sensibilidad se modelan a partir de materiales simbólicos y no de relaciones presenciales, como en las interacciones cara a cara que precedieron a la edad mediática (Thompson, 1998: 274). También nuestro sentido de 
pertenencia a grupos o comunidades con los que compartimos experiencias, se ha conformado a partir de experiencias mediáticas. J.B. Thompson (1998: 57) propone el concepto de sociabilidad mediática para referirse a los vínculos que crean los medios entre la audiencia y personas anónimas que nunca llegarán a ser conocidas de manera directa y que han dado lugar a formas de cercanía e intimidad con un otro ausente. Así, a partir de la televisión se crean relaciones de proximidad con actores, cantantes, presentadores, modelos y personajes mediáticos que pasan a ser nuestros conocidos, a formar parte de nuestras vidas, casi se incorporan a nuestra familia, buena prueba de ello es el fenómeno fandom en televisión.

La tendencia en la televisión, durante el último decenio, ha sido la proliferación de un repertorio de programas nuevos que aparecen en España heredados de fórmulas ensayadas en otros países de nuestro entorno próximo y Estados Unidos, que se suelen denominar en conjunto reality shows. Se trata de un repertorio amplio de programas muy controvertidos, de difícil definición y en evolución continua, denostados por algunos, cuestionados por todos, que han recibido apelaciones despectivas (telebasura), pero que han alcanzado lugares de privilegio en las parrillas de las cadenas (prime time) y gran éxito de audiencia, batiendo en algunos casos récords de audiencia históricos en la televisión española. No encajan en la noción tradicional de género, por lo que es frecuente hablar de formatos o programas contenedores -macrogéneros para algunos autores-, para dar cuenta de la hibridación que los caracteriza y la dificultad de su clasificación. En conjunto, se puede decir que conforman sobre todo, una tendencia en la programación de las cadenas (telerrealidad) en continua transformación.

Su principal característica es que parten de la realidad, de la mano principalmente de sujetos anónimos, pero con un tratamiento basado en la espectacularización que los aleja de ella y los convierte en una construcción social y mediática no exenta de valores e ideología. A partir de hechos reales, se construye un relato, verbal e icónico, con un alto grado de espectacularización -intimidad, hiperemotividad, dramatismo, dolor, violencia, sensacionalismo-, en el que la gente común cobra protagonismo: contando su historia personal (programas de testimonios o talk shows), exponiendo sus conflictos y sus frustraciones (programas de consultorio o confesionario), mostrando su vida cotidiana (docu-shows), haciendo un ejercicio de autosuperación para alcanzar sus sueños (concursos, realities de superación) etc. Y es precisamente el hecho de que se trata de exponer testimonios y mostrar la experiencia vital de personas comunes, lo que los acerca al telespectador y 
potencia su capacidad para generar procesos de imitación y aprendizaje social. Esto pone de manifiesto la importancia cultural del aprendizaje por observación a partir de la exposición a la televisión. Pero no se puede olvidar que se trata de una realidad espectacularizada (condición necesaria para que tenga cabida en la programación de entretenimiento que caracteriza la televisión actual), es decir con un tratamiento que utiliza técnicas de recreación, dramatización, guionización y reconstrucción, que a veces los aproxima a la ficción y los aleja de la realidad ${ }^{1}$. La realidad solo tiene atractivo para la audiencia con el aderezo de lo dramático, lo inusual, lo extremo, lo llamativo, lo escabroso, lo emotivo, en suma, lo espectacular.

La importancia de considerar estos contenidos radica por una parte, en el hecho de que es una tendencia con múltiples variantes, pero sostenida en el tiempo cuando no acrecentada, y por otra, en que ocupan una parte considerable de las parrillas en las cadenas generalistas en horario de máxima audiencia. Pero lo más relevante es que la telerrealidad es muy eficaz desde el punto de vista del aprendizaje social porque presenta modelos de conducta a partir de sujetos reales, ciudadanos comunes que podrían ser nuestros vecinos o amigos, en los que nos reconocemos y reconocemos a los otros.

\section{Televisión y Teoría del modelado}

Los programas que muestran las vidas ajenas en sus aspectos más cotidianos, tienen la virtualidad de ser una importante fuente de aprendizaje social porque se erigen en modelos de comportamiento que legitiman conductas y discursos. Ver cómo los otros resuelven sus vidas y sus conflictos, socializa. Contemplar la vida de los demás nos conforta: si es mejor que la nuestra, nos identificamos y soñamos, si es peor, nos alegramos de nuestra situación. Y esta es precisamente la cuestión más importante que se plantea desde el punto de vista del aprendizaje social: se trata de

\footnotetext{
${ }^{1}$ De hecho, es fácil encontrar numerosos ejemplos en la televisión de estos últimos años, en donde se pone de manifiesto que la realidad de las personas comunes no interesa per se. Así lo muestran el fracaso, o mínima aceptación, de programas que mezclan la técnica del reportaje con la narrativa de ficción o el docudrama, como Cercanias o Un país en la mochila, o Callejeros.
} 
programas que parten de la realidad (no de la ficción) y que sus protagonistas son sujetos comunes como nosotros, lo que les confiere verosimilitud y facilita procesos de proyección e identificación.

La teoría del modelado planteada por Albert Bandura (1982) permite explicar el funcionamiento y alcance de los modelos dentro de su teoría del aprendizaje social. La observación y posterior imitación, sería una vía de especial interés a la hora de explicar como el sujeto adquiere nuevos comportamientos y modifica sus actitudes y valores actuales; como Bandura recuerda (1974: 57), existen algunas lenguas como el español, en las que las palabras enseñar y mostrar tienen un sustrato semántico común: indicar, explicar, exponer, dar a conocer. Una parte importante del conocimiento que el individuo adquiere a propósito de la conducta y sus consecuencias, no lo obtiene por experiencia directa sobre su entorno, sino a partir de experiencias vicarias, es decir a partir de la observación de la conducta del otro.

La gente puede beneficiarse de los éxitos y equivocaciones de los demás tanto como de sus propias experiencias. En las situaciones cotidianas, se presentan numerosas ocasiones de observar las acciones de los demás y los momentos en que son recompensadas o castigadas. Para comprender las influencias de reforzamiento es fundamental considerar el papel que desempeña la observación de las consecuencias de los comportamientos de otros y ello por varias razones. Como regla general, el observar el éxito de una conducta ajena aumenta la tendencia a comportarse de forma similar, mientras que la observación de una conducta castigada disminuye la tendencia a realizarla (Bandura, 1982:144).

En el momento actual buena parte de los modelos socializadores provienen -además de la familia y la escuela, o el medio ambiente - de los medios de comunicación de masas y principalmente de la televisión que tiene un gran poder de atracción para todos los públicos. Los modelos plásticos en términos de Bandura (1974: 59) como los propuestos por la televisión o las películas, no suelen contener prescripciones explícitas para la conducta del receptor, lo que no les resta autoridad y los hace más sutiles y, sobre todo, compiten en poder de influencia con las otras instancias socializadoras. La televisión al mostrar la vida cotidiana de sujetos corrientes como nosotros, proporciona contextos de observación en los que mirarse y reconocerse y en la medida en que el receptor pueda identificarse con alguna persona o situación, interiorizará esa conducta para luego, si llega el caso, reproducirla. La adquisición y consolidación de nuevas pautas dependerá de la 
capacidad motivadora del mensaje para incentivar unas conductas e inhibir otras. Los modelos observados por el telespectador permiten anticipar sus consecuencias creando expectativas positivas si la conducta resulta recompensada (éxito, dinero, visibilidad, poder, fama) o de rechazo si obtiene una sanción negativa (invisibilidad y negación de lo anterior). De ahí la importancia de la cualidad de las sanciones que propone el medio a las conductas de sus personajes en este tipo de programas. Aunque la adquisición de dichas pautas no se lleva a cabo siempre de manera consciente e inmediata sino de forma paulatina y prolongada en el tiempo, no por ello es menos efectiva. Hoy se sabe que los principales efectos de los medios a nivel cognitivo, se producen de forma, muchas veces sutil, por acumulación y a largo plazo (Wolf, 1994).

\section{La realidad espectacularizada}

Si es acertado afirmar que una de las características de la televisión actual es el protagonismo concedido a la gente común, desde un repertorio amplio de programas en los que se muestran, con distintos tratamientos y enfoques, los entresijos de su realidad cotidiana, no es menos exacto decir que se trata de una re-construcción de esa realidad en la que se combinan elementos de drama, morbo, intimidad, hiperemotividad, de probada eficacia desde el punto de vista de conseguir grandes audiencias. Es decir, se trata de presentar la realidad pero desde el punto de vista de lo inusual, lo llamativo, lo insólito, los detalles íntimos, las emociones más vivas; en resumen, lo más sensacionalista e impactante. La propia denominación que reciben usualmente estos programas reality show, talk show, infoshow, docu-show, late night show, etc.- pone de manifiesto este carácter espectacular: el show es lo que está concebido para ser mostrado, para llamar la atención. Dicho tratamiento cumple esta función: captar la atención del televidente que zappea continuamente y retenerle delante de la pantalla para que no cambie de canal y asegurarse la audiencia que, en última instancia, garantiza la supervivencia del programa. No se puede olvidar que en la televisión actual todo aquél producto que no satisface las expectativas de aceptación por parte de la audiencia fijadas por la cadena, está condenado a desaparecer después de escasas entregas.

En el contexto de principios de los años noventa, las cadenas se ven obligadas a adaptarse, con programas de bajo coste que minimicen riesgos, a las condiciones de dura competencia por el mercado de la publicidad. Se importan, o se crean, formatos que habían tenido éxito de audiencia 
fuera de nuestras fronteras y que, en muchas ocasiones, habían sentado polémica social. Esta polémica tiene eco en otros medios, y retroalimenta así una espiral que genera nuevas audiencias interesadas no tanto en el propio contenido del programa, cuanto en la discusión y el debate social creado en torno a él.

Los reality shows comprenden un conjunto muy amplio de programas, no fáciles de categorizar dentro de un género concreto, que han ido evolucionando y transformándose a lo largo del tiempo. La noción de género ha gozado habitualmente de una acepción precisa dentro de los medios: los géneros remiten a formas convencionales de expresión, que obedecen a una actitud de su autor frente a la realidad y que reconducen las expectativas de la audiencia frente a tal realidad. Así, ha habido tradicionalmente dos ámbitos separados que han dado lugar en televisión a dos grandes tipos de programas: los programas de información y los programas de entretenimiento. Actualmente, la aparición y consolidación de estos nuevos formatos de carácter híbrido que mezclan elementos de información con entretenimiento, ha puesto definitivamente en cuestión la vigencia del concepto clásico de género, toda vez que cada día se vuelven más borrosas y difíciles de precisar las fronteras que separan la realidad de la ficción.

Desde que la realidad se ha convertido en espectáculo, todo referente tiene cabida en el ámbito de la televisión. Las pantallas se han abierto a contenidos que antes dudosamente hubieran tenido cabida en la televisión generalista por escabrosos o sensacionalistas y que hoy constituyen la línea predominante. A los programas de entrevistas y talk shows (historias de vida) por ejemplo, se han asomado con sus testimonios, personajes de toda condición: ludópatas, prostitutas, narcotraficantes arrepentidos, víctimas de sectas, presos, personajes conocidos de la vida pública o ciudadanos anónimos que un día cometieron un error y hoy buscan el perdón. Bajo el rótulo de protagonismo humano y social o con el pretexto de terapia psicológica, hemos asistido a confesiones a veces dramáticas (abusos sexuales en la infancia), a veces conmovedoras (denuncia de casos extremos), confidencias de toda índole (planear el asesinato de su esposa), arrepentimiento por algún acto cometido en el pasado y del que hoy se siente vergüenza. Con la excusa de que la confesión redime y que compartir el dolor lo hace más soportable, se han mostrado casos ejemplarizantes y se ayudado a liberarse de la culpa a quién el lastre del pasado ahoga en el presente. Se han mostrado en directo intentos de reconciliación que por desavenencias diversas, han llevado a sujetos comunes a buscar una segunda oportunidad en el programa para corregir faltas del pasado. En su vertiente 
positiva y alentadora, cartas inesperadas y sorpresas de toda índole para reconfortar al ciudadano común, mostrar la solidaridad en un momento difícil de la vida y hacer patente -en público- el afecto de amigos y familiares.

El supuesto servicio público, y también el morbo, ha llevado a algunos programas, a veces con gran despliegue de medios, a la búsqueda de sujetos desaparecidos y al reencuentro de personas separadas; reconciliaciones entre familiares, amigos o cónyuges enfadados; compañeros de trabajo y relaciones rotas que ven en el programa un mediador capaz de recomponer los lazos desgarrados por los avatares de la vida.

La muerte y sus aledaños, y la violencia en muchas de sus manifestaciones, también han sido referente de la televisión en distintos formatos. Eutanasia, enfermedades incurables, operaciones quirúrgicas, o en otro orden, violencia de género, violencia psicológica, urbana, social, delincuencia, elementos satánicos, funerarios, macabros, todo ello ha tenido presencia en nuestras pantallas quizá por la expectación que siempre despierta el hecho inexorable del final de la vida que nadie puede eludir.

El gusto por lo desconocido y el afán de trascendencia han encontrado en el esoterismo y lo paranormal una fuente importante de recursos para compensar la incertidumbre en momentos de crisis de valores. Desde los programas pioneros de los años sesenta dirigidos por el Doctor Jiménez de Oso, hasta los más recientes (Cuarto milenio), la televisión ha explotado con notable éxito de audiencia, este ámbito que ha dado acogida a curanderos, parapsicólogos, astrólogos, abducidos, milenaristas, gurús, y toda índole de sucesos sobrenaturales.

El amor y el sexo en todas sus modalidades no han escapado a los espectáculos televisivos. Parejas estables o no al borde de la ruptura, problemas de carácter sentimental y/o sexual, soledad, búsqueda del amor, conflictos que amenazan la estabilidad conyugal, han llevado a parejas o sujetos de toda edad y condición, a buscar en los programas de televisión una oportunidad para la reconciliación, encontrar ayuda para manejar sus problemas o hallar la pareja ideal.

La percepción del cuerpo y sus conflictos no ha escapado a la voracidad televisiva que recientemente ha encontrado en el cambio de imagen y la transformación drástica del cuerpo, ya sea por la vía más radical de la cirugía o por la del estilismo, entrenamiento, dieta, etc., una solución a la situación de mujeres, y algún varón, que no asumen las limitaciones de su aspecto físico y sufren a causa de sus complejos. 
En otra vertiente diferente, prestar apoyo y servicio social a los televidentes, ha configurado recientemente una televisión asistencial y de ayuda que ofrece consejos a padres que tienen dificultad para educar a sus hijos en los primeros años o para resolver conflictos con los adolescentes.

Las noticias y la información no escapan de esta tendencia espectacular que ha contaminado también a los programas de actualidad, reportajes y debate. La presión por ganar audiencia ha llevado a que la distinción entre noticias y entretenimiento se diluya. Los informativos de televisión han incluido en sus noticias acontecimientos que en otro momento no hubiesen tenido cabida por morbosos o faltos de interés periodístico, y que hoy constituyen una línea sobresaliente: sucesos insólitos, persecuciones espectaculares, catástrofes menores pero llamativas, accidentes aparatosos, escándalos e incluso frivolidades. Se prima así lo más sorprendente, lo inusual, en suma lo espectacular, en detrimento del rigor de la información y su contextualización. Todo ello facilitado por la innovación tecnológica que permite movimientos de cámara, planos e imágenes de poderoso impacto. Las noticias pierden su esencia y se convierten en un producto más de consumo cuyos principales valores son la novedad y la inmediatez sin entrar al análisis de la complejidad de la realidad. Al descontextualizar los hechos de la realidad que los origina, éstos pierden valor $-\mathrm{y}$ sentido- y éste se traslada a la novedad y la instantaneidad.

Si llamativo resulta que el contenido de los telediarios se haya deslizado hacia temas ligeros, espectaculares o mundanos, noticias blandas (Langer, 2000), no lo es menos que el ámbito de la información otrora exclusivo de los informativos, se haya trasladado a programas de naturaleza bien distinta: magacines de mañana, programas de crónica social, infoshows... Recientemente, hemos tenido ocasión de contemplar en un espacio de los denominados del corazón, un programa especial dedicado a uno de los principales casos de corrupción urbanística en una conocida localidad costera de nuestro país que ha sido objeto de una importante operación policial. Lo cuál sitúa los acontecimientos noticiosos en un contexto impropio o cuando menos ambiguo. Así, no resulta fácil determinar donde concluye la información y donde comienza el entretenimiento. El peligro de ubicar todo acontecimiento, al margen de su relevancia política, social, económica, etc., en cualquier formato comunicativo y con similar tratamiento, conduce a trivializar la realidad, magnificar la insignificancia y negar toda trascendencia social al acontecer humano además de despolitizar a la audiencia. 
Los programas de debate tampoco han escapado a esta tendencia. Tradicionalmente, este género ofrecía un intercambio dialéctico a propósito de un tema de actualidad, de forma organizada y dirigida, entre posiciones divergentes. El rol del moderador consistía en encauzar las intervenciones para que todos los invitados hagan uso de la palabra, tengan ocasión de exponer con claridad sus argumentos a propósito del tema tratado y dichas intervenciones se lleven a cabo dentro de los límites de la cortesía dialéctica. Los invitados solían ostentar una posición firme, mostrar capacidad expositiva a la hora de transmitir sus argumentos a la audiencia y eran convocados en tanto que expertos sobre la materia o, cuando menos, voces autorizadas al respecto, en virtud de su ejercicio profesional o su conocimiento públicamente reconocido. Sin embargo, en la televisión actual, los debates han devenido un espectáculo basado en la polémica. Más que debatir, para brindar a los espectadores posturas distintas, discutirlas y extraer conclusiones, se trata de presentar un enfrentamiento a veces encarnizado, entre posiciones extremas e irreconciliables sobre un tema planteado de forma maniquea, como una cuestión de apreciación o una supuesta dicotomía. Otras veces el carácter polémico proviene no de la complejidad del tema sino de los propios invitados, a quienes a menudo se ha denominado polemistas y no contertulios, para remarcar este carácter sensacionalista y provocador. La voz de los expertos se ha sustituido por el discurso desbordado y la autenticidad del sujeto común cuando no del diletante, como modelo de conocimiento y opinión cualificada.

En otro ámbito diferente, el deporte profesional televisado es buen ejemplo de la tendencia espectacular de la televisión actual, en donde la confrontación deportiva se diría que pierde importancia al lado de la creación de un espectáculo de masas susceptible de fidelizar a la audiencia. En deportes como el fútbol, el automovilismo o el ciclismo, se puede afirmar que lo importante no es solo a favor de quién se decide la victoria en la competición, sino su capacidad para generar un producto comunicativo atractivo y competitivo respecto a la programación de las restantes cadenas. Los clubes de fútbol, por ejemplo, se han transformado en sociedades anónimas que se organizan y gestionan en función de los resultados económicos y éstos dependen en buena parte, de su capacidad para generar un espectáculo en la televisión que proporcione grandes audiencias. Las retransmisiones deportivas, muestran al detalle todos los elementos del espectáculo mediático: primerísimos planos, perspectivas inéditas de las jugadas, repeticiones ralentizadas, la alegría de la victoria o el dolor de la derrota reflejados en la expresión del rostro de los jugadores, declaraciones de árbitros y directivos 
del equipo, réplicas y contrarréplicas, antecedentes y consecuentes del partido, comentarios, polémica si la hubiere por una actuación arbitral discutible, actuaciones ritualizadas por parte de los jugadores a la hora de celebrar la jugada...todo ello convierte la retransmisión del encuentro en algo más que un juego: un espectáculo televisivo que no pretende mostrar lo que ocurre en el estadio tal como sería percibido por un espectador ideal, sino re-crearlo desde coordenadas mediáticas.

Al diluirse las fronteras entre lo ficticio y lo real, la televisión ha dejado de mirar al mundo para crear un universo propio y autorreferencial, buena prueba de ello son los programas de zapping que explotan bajo diversos rótulos (actualidad y reportajes, entretenimiento y humor) imágenes ya emitidas por las cadenas (Cáceres, 2005). La televisión actual, entre realidad y ficción, ha creado -y re-creado- sus propios acontecimientos -acontecimientos mediáticos (Cáceres, 2001: 157)- es decir aquellos hechos que no tendrían existencia si no es porque el medio está ahí para dar cuenta de ellos. En nuestras pantallas abundan espacios en los que se muestran situaciones y personajes cuyo protagonismo está en función del medio. Por ejemplo, los reality shows presentan situaciones concebidas ex profeso para la televisión -como Gran Hermano y modalidades posteriores- o cuando menos, reconstruidas en el plató de televisión, para que los sujetos muestren en público su arrepentimiento, demanden perdón, se reconcilien con su pareja o relaten en directo, los detalles íntimos de su existencia. Los programas de vídeos domésticos muestran situaciones supuestamente hilarantes, cuya existencia sería más que dudosa si no fuera porque había allí una cámara dispuesta a captar ese instante. Ciertamente, se trata de programas que parten de la realidad puesto que el referente tiene existencia real y los actores también son personas reales, no obstante en cierta medida son ficcionales porque esa realidad no existiría, o al menos no sería igual, si las cámaras no estuvieran presentes. Por ejemplo, no es concebible que exista un espacio -o Academia- en donde un grupo de jóvenes conviven y se forman durante unos pocos meses, para mostrar su esfuerzo cotidiano y someter sus progresos al juicio de profesionales y profanos si no es para ser mostrado por la televisado (Cáceres, 2002). Dicho en otros términos, se trata de una realidad con guión, de una realidad re-creada artificialmente aunque con gran poder de verosimilitud, de ahí haya perdido sentido hablar de géneros en la acepción clásica del término.

\section{Realismo percibido}


De todos es sabido que la atribución de realidad que el espectador realiza al contemplar la televisión es un factor decisivo en la determinación de los efectos que ese espacio tendrá. El hecho de que se trate, la mayor parte de las veces, de personas reales, ciudadanos comunes que muestran su vida cotidiana, puede hacer creer que la realidad es así. En este sentido, estos programas constituyen una representación válida de cómo son las personas, de cómo se comportan y de cómo ocurren los hechos. El realismo percibido contribuye a que la audiencia interiorice esa representación como una propuesta de realidad con virtualidad para canalizar procesos de proyección e identificación, que proporcionan seguridad e integración al ver que sus problemas o inquietudes son compartidos por otros, empatía social y gratificación psicológica al comprobar que su situación personal es menos dolorosa que la de los protagonistas del programa, o simplemente con valor heurístico a propósito de la vida en general.

A menudo, se olvida que lo que aparece en la pantalla no es la realidad y que la televisión no muestra toda la realidad. Detrás de todo producto comunicativo, hay un proceso de mediación: selección y tratamiento que circunscribe esa realidad a la construcción formal y de contenido que hace el medio para cada programa. Esta mediación pasa por una parte, por ajustar el espacio y tiempo del suceder, al espacio y tiempo mediáticos en formas expresivas previsibles y reconocibles por el receptor; y por otra, por una selección y organización a nivel de contenido que tiene cómo resultado una construcción argumental, trama o historia susceptible de interesar a la audiencia. Dicho en otros términos, la televisión no muestra la realidad tal cual sucede, sino una realidad recreada en el plató que obedece a criterios organizativos y comunicativos, rutinas profesionales e intereses de la cadena (Cáceres, 2000). En resumen, lo que se muestra es real, porque se trata de personas reales en situaciones reales, pero con un tratamiento que lo acerca a la ficción. En otros casos, la realidad es creada ex profeso para ser mostrada y en otros puede afirmarse que dicha realidad no existiría tal cuál si no es porque están las cámaras para dar cuenta de ella. Como plantea R. Debray (1994: 304) a propósito de la era visual, lo real no se convierte automáticamente en verdadero $^{2}$. Podríamos añadir que los acontecimientos que muestra la telerrealidad no son verdaderos ni falsos, sino acontecimientos mediáticos.

\footnotetext{
${ }^{2}$ Esto incide en la ecuación que critica el autor en la que lo visible equivale a lo real y lo real a lo verdadero.
} 


\section{El espectáculo de la emoción}

Hasta la generalización de las nuevas formas expresivas de la Neotelevisión (Eco, 1986), la televisión se ocupaba de lo público; de hecho, en terminología comúnmente aceptada, se habla de comunicación pública como sinónimo de medios de comunicación de masas, para aludir precisamente a este aspecto: la televisión en particular y los medios en general, se ocupan de dar a conocer a una audiencia masiva y anónima, los temas de interés público, aquellos que trascienden la vida privada del individuo y conciernen a los asuntos de la comunidad.

En el momento actual, se ha producido un quiebro en esta concepción y la privacidad del sujeto y su vida íntima se ha incorporado a la televisión con connotaciones comerciales. La noción de intimidad alude a la esfera más profunda, interna y propia del sujeto, a la vida psíquica y a la conducta en ese ámbito personalísimo reservado a las afecciones, donde se ubican los sentimientos y las emociones y donde los demás no tienen cabida sin previa autorización. Del mismo modo que el sujeto necesita un espacio físico a su alrededor que no puede ser traspasado por los demás (algunos autores lo denominan burbuja, otros espacio personal) porque le confiere seguridad y le hace sentirse a salvo -el espacio vital-, también existe un espacio existencial y experiencial que pertenece sólo al sujeto. Si bien es cierto que las nociones de privacidad e intimidad no son exactamente asimilables, no lo es menos que se hallan muy próximas. Lo privado se opone a lo público, ocupa un espacio que escapa a los ojos ajenos y resulta desconocido a menos que lo demos a saber; la intimidad se relaciona con la parte más secreta del ser, su esencia y su identidad. Intimidad y privacidad a veces coinciden totalmente o en parte, otras veces se superponen y complementan como zonas adyacentes en el comportamiento humano. Ambos aspectos trascienden a la esfera pública en nuestra televisión, que muestra impúdicamente los lugares más recónditos del alma humana con la aquiescencia de sus protagonistas. Los límites entre el espacio público y privado se desdibujan y se pierden en otro espectacular e hiperrealista, donde todo tiene cabida, a condición de exhibir sus más mínimos detalles.

La exhibición desmedida de la intimidad está encaminada a provocar emociones vivas en el receptor, a que se identifique o proyecte su yo en lo que ocurre en la pantalla y así hacerle partícipe del gran espectáculo hiperrealista de las emociones televisadas. La televisión postmoderna apela a la emoción frente a la razón, para ello despliega una serie de estrategias comunicativas (uso efectista de la imagen, primeros planos, discurso extremo, situaciones límite, pasiones exacerbadas) destinadas a 
provocar la catarsis en el espectador. La televisión hace vivir la emoción, no la muestra o simboliza, sino que la provoca (Sánchez Noriega, 2002), busca la implicación emotiva del receptor.

La hiperrealidad televisiva ha revalorizado la emoción en todas sus dimensiones: la pasión amorosa, la alegría desmedida, el gusto por el riesgo, el odio, la frustración, la pérdida, el dolor, el sufrimiento agudo, etc. (Cáceres, 2004: 44), y las ha incorporado al mercado audiovisual de la mano de imágenes impactantes destinadas a satisfacer aquí y ahora, la tensión entre exhibicionismo y voyerismo que plantea Bourdieu (1997:70). El éxito del culto a la emoción radica en que entraña autenticidad porque sucede de verdad. Se trata de historias realmente vividas por personas comunes como cualquiera de nosotros. Lo auténtico nos hace sentir y, en ocasiones, vivir intensamente. A este respecto, Lipovetsky (1986) plantea la condición del hombre postmoderno que descree del porvenir y de un sentimiento proyectual de su existencia. Su vida, concebida como un continuo presente, alimenta un hedonismo que hace de su cuerpo el soporte de su identidad y le empuja a vivir intensamente, a sentir más y, llegado el caso, a vibrar en directo.

Al hombre postmoderno le interesa vivir intensamente aquí y ahora un conjunto de placeres y emociones que conectan con la era del feeling (Finkielkraut, 1988). Así, por ejemplo, el programa "Factor miedo" de no muy lejana exhibición en nuestras pantallas, mostraba, a modo de concurso entre tres participantes, pruebas extremas que entrañaban riesgo, peligro, alta competitividad y miedo. El programa que se saldaba con el éxito de sólo uno de ellos, se basaba en un discurso extremo que apoyaba la tesis de que la vida sólo merece la pena si se vive intensamente. Los concursantes vivían el peligro, el miedo e incluso el riesgo de morir: eso es lo que proporcionaba emoción y autenticidad a la experiencia. Para los dos concursantes fracasados sólo quedaba frustración, envidia y vergüenza, como así lo expresaba, en una de las entregas del programa, una de las concursantes, bombera de profesión, que manifestaba no osar volver a su entorno laboral por la humillación sufrida en la competición.

La televisión propugna la emoción per se; emoción magnificada y re-creada, emociónespectáculo, en suma. Las imágenes impactantes y el discurso extremo como estrategias que despliega el medio, están encaminadas a la fascinación más que a la reflexión, por eso la televisión seduce, más que convence. 


\section{El poder de la imagen}

La televisión actual al primar lo emotivo frente a la racionalidad, ha conducido a una hipertrofia de la emoción a partir principalmente de un elemento expresivo de profundo calado como es la imagen. R. Debray comienza el prólogo de su célebre texto sobre la imagen (Debray, 1994: 13) comentando la vaga inquietud que le produjo aquella vieja leyenda china que narra como el emperador pidió a su primer pintor de corte que borrara la cascada que había pintado al fresco en los muros de su palacio, porque el ruido del agua le impedía dormir. Tal es el poder movilizador de la imagen.

La imagen conecta directamente con la emotividad y en esta medida es perturbadora del equilibrio homeostático que el sujeto tiende a restablecer y dar una salida a esa energía emotiva en un sentido concreto que orienta la conducta. Las imágenes en tanto que inciden en el ámbito emocional conectan con deseos, aspiraciones, temores y necesidades; es decir conectan con los sentimientos y pasiones humanas y en la medida en que los reflejan o activan, los concretan en una dirección determinada(Ferrés, 1997: 48). En este sentido, la imagen es siempre una propuesta de realidad. Por ejemplo una imagen que conecta con la felicidad y activa tal aspiración en el telespectador no se agota en sí misma, sino que proporciona una dirección a la satisfacción de tal deseo. La imagen sugiere qué es lo que proporciona felicidad; dicho en otros términos la situación, personas, hechos o productos mostrados se presentan como un modelo de felicidad. "En definitiva cada vez que la imagen conecta un sentimiento con una realidad, está confiriendo sentido a esa realidad" (Ferrés, 1997: 49). Así pues, la imagen moviliza en una dirección concreta que viene marcada por la significación que cobra para el receptor. De tal modo, el emperador chino se veía forzado a eliminar la cascada cuyo fragor le impedía conciliar el sueño.

La dimensión emocional y espectacular de la televisión se relaciona directamente con la omnipresencia de la imagen, facilitada por la innovación tecnológica que permite en el momento presente planos, ángulos y movimientos de cámara inimaginables en otro momento. La aligeración de los equipos técnicos así como la miniaturización unidas a la calidad y definición de la imagen, permiten captar situaciones y detalles otrora impensables, además de construir un discurso fragmentado y muy rápido destinado a evitar que el receptor cambie de canal. En efecto, en el momento actual no hay información ni programa en el que la imagen no tenga un peso substancial, incluidos los telediarios. De hecho, como los profesionales del ámbito periodístico bien conocen, 
éste es un criterio relevante a la hora de seleccionar qué sucesos formarán parte de la agenda informativa del día.

El imperativo profesional vigente en la actualidad de que no puede haber noticia sin imagen conduce a situaciones de carácter paradójico. Recientemente, hemos contemplado en el telediario de una cadena generalista, la noticia de un atentado sufrido por las tropas españolas en Afganistán, en donde pereció un soldado español además de resultar heridos otros dos, en una misión de apoyo a las tropas italianas. Los soldados españoles aparecían riéndose en las imágenes que acompañaban la información. Sin duda el celo profesional del periodista le llevo a incluir éstas que no se correspondían al acontecimiento de referencia, ante la falta de otro material gráfico, pero que en este caso ponían en entredicho la gravedad del suceso. Además, el telespectador no siempre está en posición de distinguir cuando las imágenes son reales o simuladas. Así por ejemplo, para el sujeto no es posible discernir si las imágenes de la estación espacial MIR que contempla en su televisor, son auténticas o se trata de una simulación realista. Pero en el fondo no importa, en el momento presente se diría que la imagen es un valor en sí misma, al margen de lo que muestra y su autenticidad. Durante la guerra del Golfo en 1991, se difundió mundialmente la imagen conmovedora de un cormorán agonizante envuelto en petróleo para mostrar el incendio de los pozos petrolíferos. Luego se supo que la imagen correspondía a un desastre ecológico ocurrido en Alaska en 1989.

La omnipresencia de las imágenes, incluso en ocasiones de forma gratuita, se pone de manifiesto en la repetición reiterada de las mismas como ilustración del discurso verbal. Es frecuente, contemplar que en muchos programas se acompaña la narración sonora de todo tipo de acontecimientos desde los más frívolos e intrascendentes a los más significativos, de imágenes que se repiten redundantemente sin aportar elemento alguno de novedad y por lo tanto faltas de interés una vez conocidas. Dicho en otros términos, la imagen deja de mostrar o ilustrar el hecho o la situación, toda vez que ya es conocido -se ha visto-, no obstante ante la carencia de nuevas imágenes, éstas se reiteran, incluso repetidamente a lo largo del programa.

Otras veces el material gráfico que aporta el programa carece de valor periodístico, no obstante se muestra como para paliar una suerte de horror vacui visual o evitar el derrumbe de esa noticia. Tal es el caso de personajes que en lugares públicos son asaltados y preguntados pero declinan contestar, otros hacen caso omiso de la presencia del periodista y continúan su camino al margen del acoso al que a veces se ven sometidos por los micrófonos y la omnipresencia de la 
cámara intentando arrancar unas declaraciones no deseadas. En todos estos casos dichas imágenes sustraídas a la voluntad de sus actores, no aportan elemento alguno de interés: la no respuesta y la no participación en un juego no vinculante, más bien podría decirse que son la antítesis de lo que el reportaje debería exhibir. En otra línea diferente, los video-clips que acompañan la promoción de los lanzamientos musicales son un buen ejemplo de la ausencia de relación directa entre el contenido de la composición musical y la narración visual: se trata simplemente de un collage de imágenes, en ocasiones muy bellas, cuidadas, técnicamente sofisticadas. Es difícil encontrar una expresión más palmaria del famoso aforismo de MacLuhan "el medio es el mensaje".

\section{A modo de conclusión}

Si nadie pone en cuestión que la televisión es una instancia de referencia que socializa y fomenta conductas y esquemas desde los que pensar y valorar la realidad, cabría plantearse los límites a lo que puede y debe ser mostrado por el medio. Exhibir la intimidad y la emoción dramatizadas- en todas sus versiones, convertidas en un producto entretenido y fácilmente consumible, banaliza dichas conductas y a los sujetos que las padecen. Su visibilidad sin ningún género de cortapisas, conduce a la obscenidad de que todo puede ser mostrado, al amparo de la libertad de expresión y la capacidad de elección de la audiencia soberana .

Lo secreto, lo íntimo, lo privado, siempre despierta interés; la alegría como la tristeza o el dolor, resultan atractivos para el otro porque todos podemos padecerlos en algún momento. Compartir la intimidad de un otro ausente proporciona empatía social e integración y compensa de los efectos disgregadores del cambio en una sociedad que ha convertido la pluralidad en relativismo axiológico. Pero el afán desmedido por hipervisibilizar (con fines lucrativos) incluso lo invisible -las emociones, los sentimientos, las pasiones humanas convertidas en un producto más de consumotiene sus riesgos: insensibilizar ante el dolor humano, producir una imagen distorsionada de la realidad, empobrecer la percepción del mundo, magnificar la insignificancia y no discernir lo trivial de lo importante. Además, ahondar y mostrar públicamente los aspectos que indagan en los rincones más escabrosos del psiquísmo puede fomentar tendencias morbosas, como así lo prueban el éxito del cine gore, las snuff movies o la complacencia de la audiencia ante las recientes imágenes del 
ahorcamiento de Sadam Hussein colgadas en Internet. La complejidad del alma humana hace que no siempre sean previsibles las consecuencias de los móviles que en cada caso resultan activados.

El discurso emotivo e impactante de la telerrealidad no permite tomar distancia y adoptar una postura crítica y de cuestionamiento, deseable desde la función formadora legítimamente atribuida a la televisión, más bien induce a permanecer en lo inmediato, a consumir el producto y renovarlo por otro más actual. No quiere decirse que el aprendizaje deba disociarse del entretenimiento, ambos no tienen por qué remitir a ámbitos contrapuestos sino complementarios, e idealmente en parte coincidentes, de ahí la importancia de abordar, desde el punto de vista del modelado social, la virtualidad de las nuevas formas expresivas que ha adoptado la televisión, explorar sus posibilidades y limitaciones.

A menudo la justificación a estos contenidos se lleva a cabo desde el criterio último de la audiencia, pero el hecho de que un programa goce de una aceptación masiva, no lo convierte en aceptable desde el punto de vista de la calidad y deseable desde el punto de vista de la sociedad. Aquel es un criterio basado en la lógica del mercado que olvida las implicaciones sociales, políticas, ideológicas y culturales que tiene cualquier producto comunicativo. Conviene recordar que el discurso de la televisión como todos los discursos sociales no es inocente, por connotación, implicación y suposición, contiene contenidos latentes (Morley, 1996) que conforman simbólicamente la realidad.

\section{Bibliografía}

- AGUADED, J.I., 1999: Convivir con la televisión. Familia, educación y recepción televisiva, Paidós, Barcelona. 
- BANDURA, A.,1974: Aprendizaje social y desarrollo de la personalidad, Alianza, Madrid.

- BANDURA, A., 1982: Teoría del aprendizaje social, Espasa Calpe, Madrid.

- BOURDIEU, P.,1997: Sobre la televisión, Anagrama, Barcelona.

- CÁCERES, M.D.,2000: La crónica rosa en televisión o el espectáculo de la intimidad en CIC, 5, Madrid.

- CÁCERES, M.D.,2001: La mediación comunicativa: El programa Gran Hermano en ZER, 11, Bilbao.

- CÁCERES, M.D.,2002: Operación Triunfo o el restablecimiento del orden social en ZER, 13, Bilbao.

- CÁCERES, M.D..2004: Realities de superación. Nuevo espejo televisivo en Telos, 58, Madrid.

- CÁCERES, M.D., 2005: Humor y zapping: espectáculo de la postmodernidad, en Cuesta, U., La comunicación social contemporánea, Universidad Complutense, Madrid.

- CASTAÑARES, W., 2007: La televisión moralista. Valores y sentimientos en el discurso televisivo, Fragua, Madrid.

- DEBRAY, R.,1994: Vida y muerte de la imagen, Paidós, Barcelona.

- ECO, U.,1986: La estrategia de la ilusión, Lumen, Barcelona.

- FERRÉS, J.,1997: La televisión subliminal, Paidós, Barcelona.

- FERRÉS, J.,1998: Televisión y Educación, Paidós, Barcelona.

- FINKIELKAUT, A.,1988: La derrota del pensamiento, Anagrama, Barcelona.

- IMBERT, G.,2003: El zoo visual, Gedisa, Barcelona.

- LANGER, J.,2000: La televisión sensacionalista: el periodismo popular y las “otras noticias”, Paidós, Barcelona.

- LIPOVETSKY, G.,1986: La era del vacío: ensayos sobre el individualismo contemporáneo, Anagrama, Barcelona.

- MORLEY, D.,1996: Televisión, audiencia y estudios culturales, Amorrortu, Buenos Aires .

- RODRÍGUEZ PASTORIZA, F.,1997: Perversiones televisivas. Una aproximación a los nuevos géneros audiovisuales, Instituto de Radiotelevisión Española, Madrid. 
- SÁNCHEZ NORIEGA, J.L.,2002: Crítica de la seducción mediática, Tecnos, Madrid.

- THOMPSON, J. B.,1998: Los Media y la modernidad. Una teoría de los medios de comunicación, Paidós, Barcelona.

- WOLF, M.,1994: Los efectos sociales de los Media, Paidós, Barcelona. 